\author{
ACTA AGROBOTANICA \\ Vol. 63 (2): 33-40 \\ 2010
}

\title{
THE LOCATION OF NECTARIES AND NECTAR SECRETION IN THE FLOWERS OF Allium giganteum REGEL
}

\author{
${ }^{1}$ Beata Żuraw, Elżbieta Weryszko-Chmielewska \\ ${ }^{2}$ Halina Laskowska, Elżbieta Pogroszewska \\ ${ }^{1}$ Department of Botany, University of Life Sciences, Akademicka 15 \\ 20-950 Lublin, Poland, e-mail: beata.zuraw@up.lublin.pl \\ ${ }^{2}$ Institute of Ornamental Plants and Landscape Architecture, University of Life Sciences \\ Leszczyńskiego 58, 20-068 Lublin, Poland, e-mail: halina.laskowska@up.lublin.pl
}

Received: 28.06.2010

\begin{abstract}
In the flowers of Allium there are found septal nectaries; in particular species, their outlet can be located in different parts of the ovary. The inflorescences of these plants are a rich source of nectar for insects.

The location and structure of septal nectaries in the flowers of Allium giganteum Regel were investigated. Light and scanning electron microscopy was used. The septal nectaries were found to be located in the lower part of the ovary and in the gynophore on which the ovary is borne. Nectar is secreted into the nectary slits from which it flows through the ducts to three openings located in the upper part of the gynophore, from whence it gets outside in the vicinity of the expanded parts of the filaments. Sugar concentration in the nectar of A. giganteum averaged $54.5 \%$, while sugar weight per flower was determined to be $0.36 \mathrm{mg}$. When converted into sugar weight per inflorescence, numbering more than 2,000 flowers, it was $771.7 \mathrm{mg}$.
\end{abstract}

Key words: onion (Allium L.), ecological features of flowers, micromorphology, anatomy, nectaries, nectar

\section{INTRODUCTION}

Many species of the genus Allium produce impressive, intensely coloured inflorescences and for this reason they are grown as ornamental plants (Kamenetsky and Fritsch, 2002).

Allium giganteum Regel is native to the Himalayas and Central Asia. It produces high inflorescence stems that may reach a height of $125-200 \mathrm{~cm}$. Heather or purple-red flowers are clustered in globular dense inflorescences with a diameter of 10-12 cm, sometimes reaching $20 \mathrm{~cm}$ in diameter. The plants flower from May to July. They are planted as individual specimens in green areas as well as they are used for cut flowers and dry floral arrangements ( $\mathrm{H} \mathrm{e} \mathrm{r} \mathrm{tog}$ h de and $\mathrm{Zi} \mathrm{m}$ mer, 1993; Kamenetsky and Fritsch, 2002; Kr z y m iń s k a, 2003, 2008).

Bees belong to insects pollinating flowers of Allium genus plants and they visit these flowers in great numbers (M urizio and Graf1, 1969; Żuraw, 2007). Earlier research shows that these plants can be an abundant source of pollen and nectar for bees (Ż u r a w, 2007, 2008; $\dot{Z}$ u raw et al. 2009).

In the flowers of Allium genus plants there are found septal nectaries located in the septa of the ovary ( $\mathrm{R} \mathrm{u} \mathrm{d} \mathrm{a} \mathrm{11,} \mathrm{2002).} \mathrm{The} \mathrm{nectar} \mathrm{produced} \mathrm{in} \mathrm{them} \mathrm{flows}$ out onto the surface through the ducts. In particular species, the outlet of the ducts is located at the apex of the ovary (S mets et al. 2000), at half height of the ovary (M a uri zi o and Graf 1, 1969; $\dot{Z}$ u raw, 2008), or in its basal part ( $\dot{Z}$ u r a w et al. 2009).

Currently, we continue our research on the location of nectaries in the flowers of various Allium species. This paper covers a comparative study on the location and structure of nectaries as well as the location of the nectar outlet in the flowers of Allium giganteum Regel. We also estimated the nectar production rate and sugar content in the nectar of this species.

\section{MATERIALS AND METHODS}

The anatomy and micromorphology of the ovary as well as the location and structure of the nectary in Allium giganteum Regel were investigated. The structural features of the lower part of the filaments, protecting the nectar against flowing out of the flower, were also determined. The studied plants came from a collection of the Department of Ornamental Plants of the University of Life Sciences in Lublin. 
Microscopic slides for light microscopy (LM) examination were prepared from hand-cut sections made from fresh plant material and material fixed in $70 \%$ ethanol. In order to locate the septal nectaries, cross sections were made at different levels of the nectary and the gynophore.

The material for scanning electron microscopy (SEM) examination was fixed in $4 \%$ glutaraldehyde in $0.1 \mathrm{M}$ phosphate buffer for 4 hours at room temperature. The samples were dehydrated in ethanol and acetone series. Then, they were critical-point dried in liquid $\mathrm{CO}_{2}$ and coated with gold. Observations were performed in a BS-340 Tesla microscope.

The nectar production rate was investigated in 2010. The method described by J a bło ń ski (2003) was employed. At full flowering, when more than half of the flowers were open, 10 buds in each of 4 inflorescences were marked and the whole buds were isolated in order to prevent insect access. The marked flowers were picked on the date of maximum nectar accumulation in them (3rd day of flowering) and taken to the laboratory. The nectar was collected into micropipettes, four nectar samples from each of the 10 flowers. After the determination of nectar weight, sugar concentration in the nectar was determined using a refractometer. To determine the day on which maximum sugar concentration occurred in the flower, three samples, with 10 flowers each, were collected on day 1,2 , and 3 of the flower's life. The number of flowers per inflorescence was examined in 5 plant specimens.

\section{RESULTS}

\section{Floral morphology}

Large Allium giganteum inflorescences, with more than 2,000 flowers clustered together, determine the ornamental values of this species (Figs 1-3). As many as 3,000 flowers were found in some inflorescences, on average 2144 .

The purple tepals, stamen filaments, and the style, contrasting with the green ovary, are the colour attractants for insects (Figs 4-7). The stamens protrude above the tepals. The filaments of the inner whorl of stamens are flattened and expanded at the base (Figs $6,13)$, whereas in the upper part they are cylindrical (Fig. 14). Large parenchymal cells occur underneath the layer of elongated epidermal cells (Fig. 15). The stamens of both whorls were fused together at the base. They are also attached to the tepals.

In lateral view, the ovary of the pistil is slightly flattened (Figs 5, 7), and viewed from above, it has a triangular contour (Figs 8, 10-12). The ovary is borne on a short gynophore (Figs 5, 7, 9, 19, 20). The epidermal cells of the ovary have the form of papillae (Figs $16,17,23,24)$ whose surface is covered with a striated cuticle (Fig. 18).

\section{Nectaries}

The septal nectaries in the flowers of $A$. giganteum are located in the lower half of the ovary (Figs 10, 11, 25). They are composed of three parts, corresponding to the nectary septa. They are best developed in the lower situated regions of the ovary where the septa are much wider. Large ovary chambers are found at the upper boundary of the nectary, and the septa are more poorly developed here (Fig. 12). The epithelial layer of the nectary is made up of one tier of nectar-secreting cells (Figs $23,24)$.

We observed the location of the nectary in the ovary septum also in longitudinal section (Fig. 25). The most expanded part of the nectary is located slightly below the half-height of the ovary. At a level corresponding to about $1 / 3$ of the height of the nectary slit, there is a connection with the duct through which the nectar flows outside. The location of this duct next to each of the three parts of the nectary can also be seen in the cross-sectional view of the ovary (Fig. 22). The outlet of the duct is situated in the gynophore, beneath the ovary (Figs 20, 21, 25). The expanded stamen filaments are located opposite the places of nectar emission.

\section{The nectar production rate}

The flowers of the plants under study secreted nectar already on the first day of their life, at the stage of pollen shed from the stamens. The nectar gradually accumulated and reached a maximum weight of $7.0 \mathrm{mg}$ on the 3rd day of the flower's life (Fig. 26), when the anthers were already empty of pollen and the style was elongated to its maximum extent. On the third day of the flower's life, the analyzed nectar was characterized by high sugar concentration, ranging $38.0-72.8 \%$ (on average $54.5 \%$ ). Sugar weight per 10 flowers, determined for the entire flower lifetime, was $3.34-4.14 \mathrm{mg}$ (on average $3.60 \mathrm{mg}$ ). The calculations show that sugar yield per inflorescence reached a value of $771.66 \mathrm{mg}$.

\section{DISCUSSION}

Numerous papillae are found on the surface of the ovary in the pistil of A. gigantem; morphologically, they are close to similar outgrowths found on the epidermis of the perianth segments in many plants (Voge 1, 1990; Weryszko-Chmielewska and $\mathrm{Ch}$ wi 1, 2008; Kon ars k a , 2009) as well as on the stamen filaments in Asphodelus (Weryszko$\mathrm{Ch} \mathrm{mielewska}$ et al. 2007). The papillae described in the abovementioned papers participated in the emission of essential oils. It is therefore probable that in Allium the tissues responsible for the production and emission of odorous compounds are located in the ovary of the pistil. 

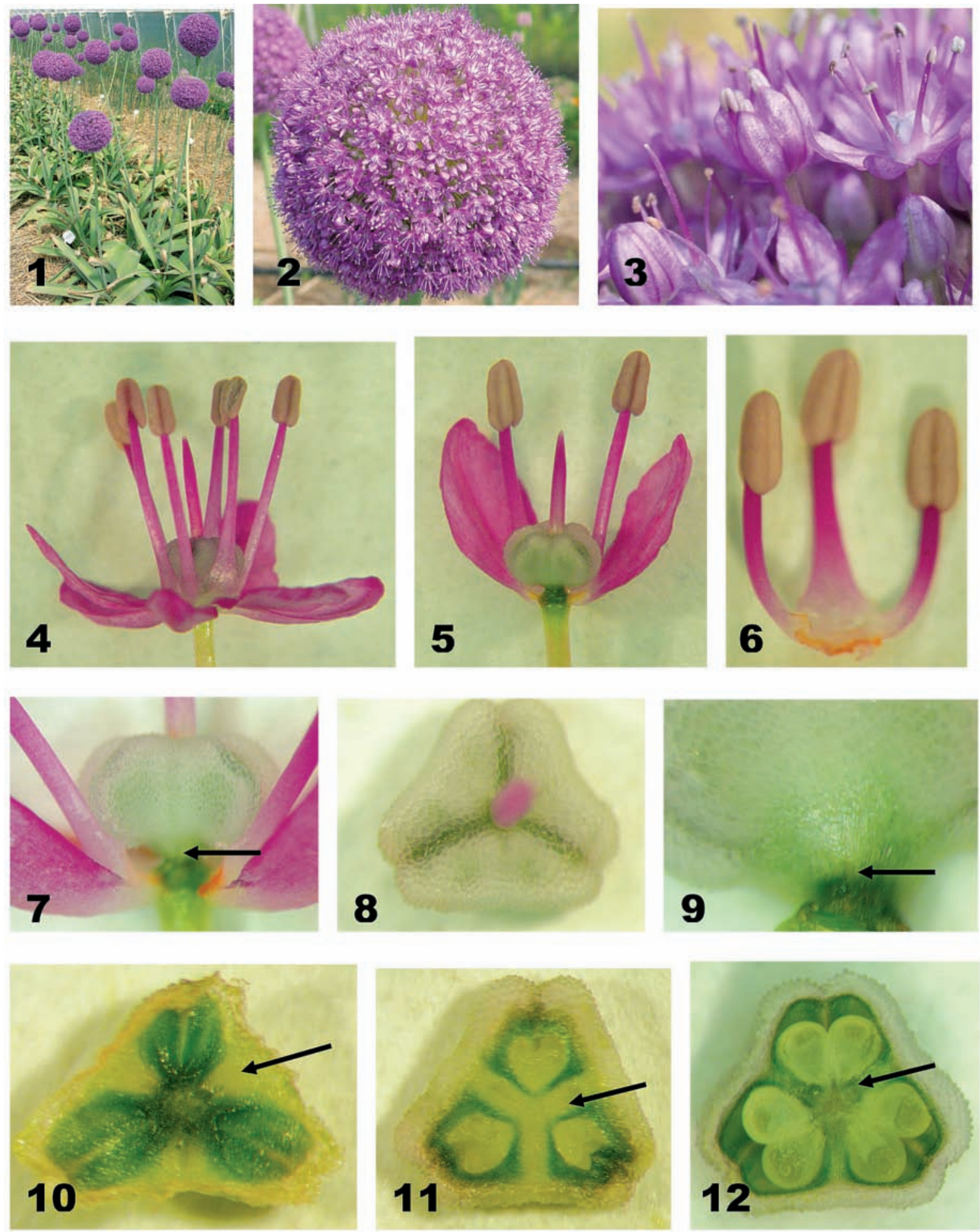

Figs 1-3. Inflorescences of Allium giganteum

Figs 4, 5. Flower portions with the visible pistil and androecium, $\mathrm{x} 6$

Fig. 6. Stamens fused at the basal part of the filaments. The middle stamen with an expanded lower part of the filament is from the inner whorl, $x 8$

Fig. 7. A portion of a flower with the marked outlet of the duct through which the nectar flows (arrow), $x 15$

Fig. 8. Top view of the pistil, $x 15$

Fig. 9. The lower part of the ovary with the gynophore in which the nectar outlet is indicated with an arrow, $\mathrm{x} 30$

Figs 10-12. Cross sections of different levels of the ovary, located increasingly higher. Visible are the septa of varying width in which the nectaries are located (arrows), x 18 

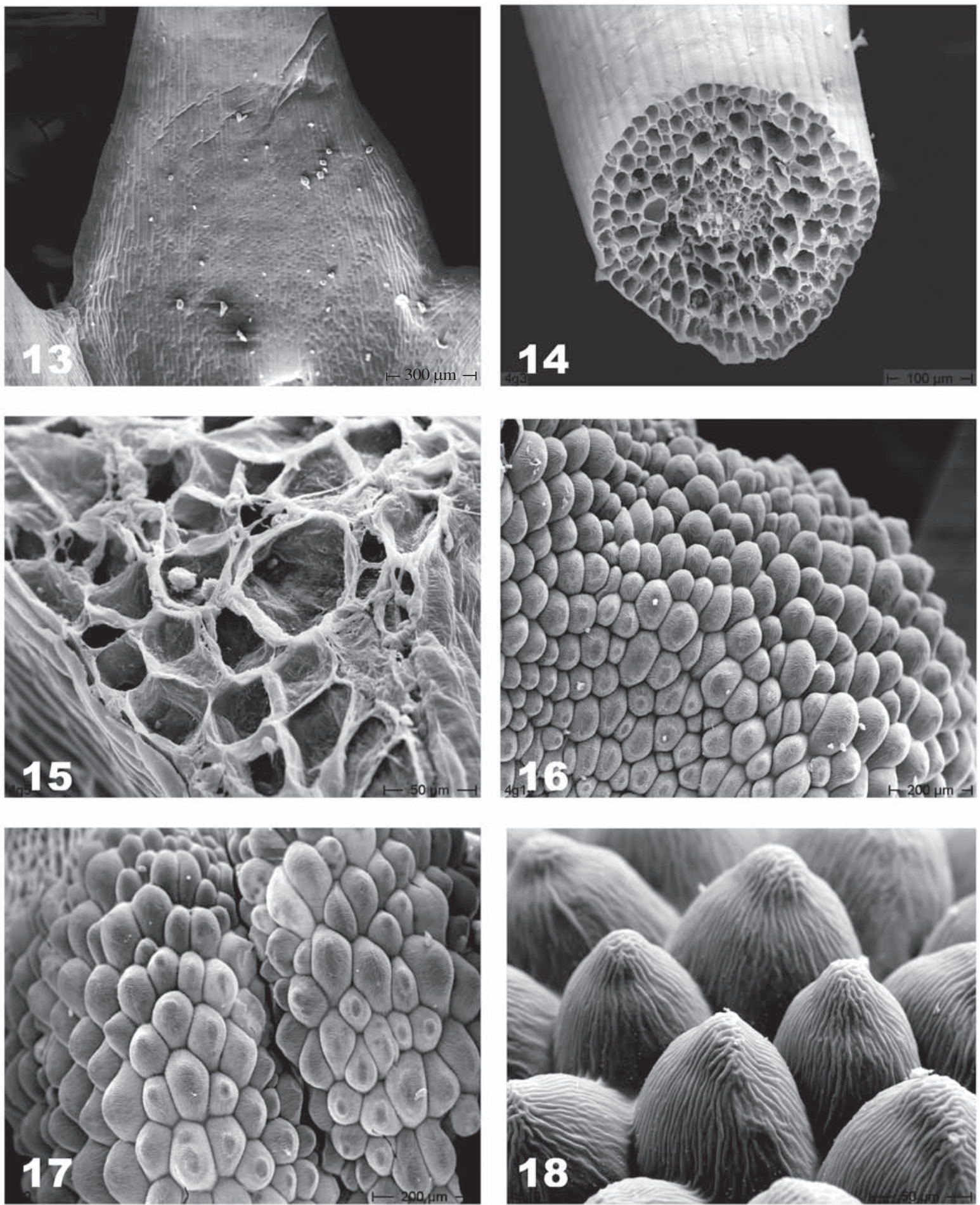

Fig. 13. The expanded part of the filament from the inner whorl of stamens

Fig. 14. A portion of the upper part of the filament

Fig. 15. A cross-sectional portion of the lower part of the filament: from the left, the epidermis and parenchymal cells of different size

Figs 16, 17. Surface portions of the ovary with visible epidermal papillae

Fig. 18. Epidermal cells forming papillae covered with a striated cuticle 

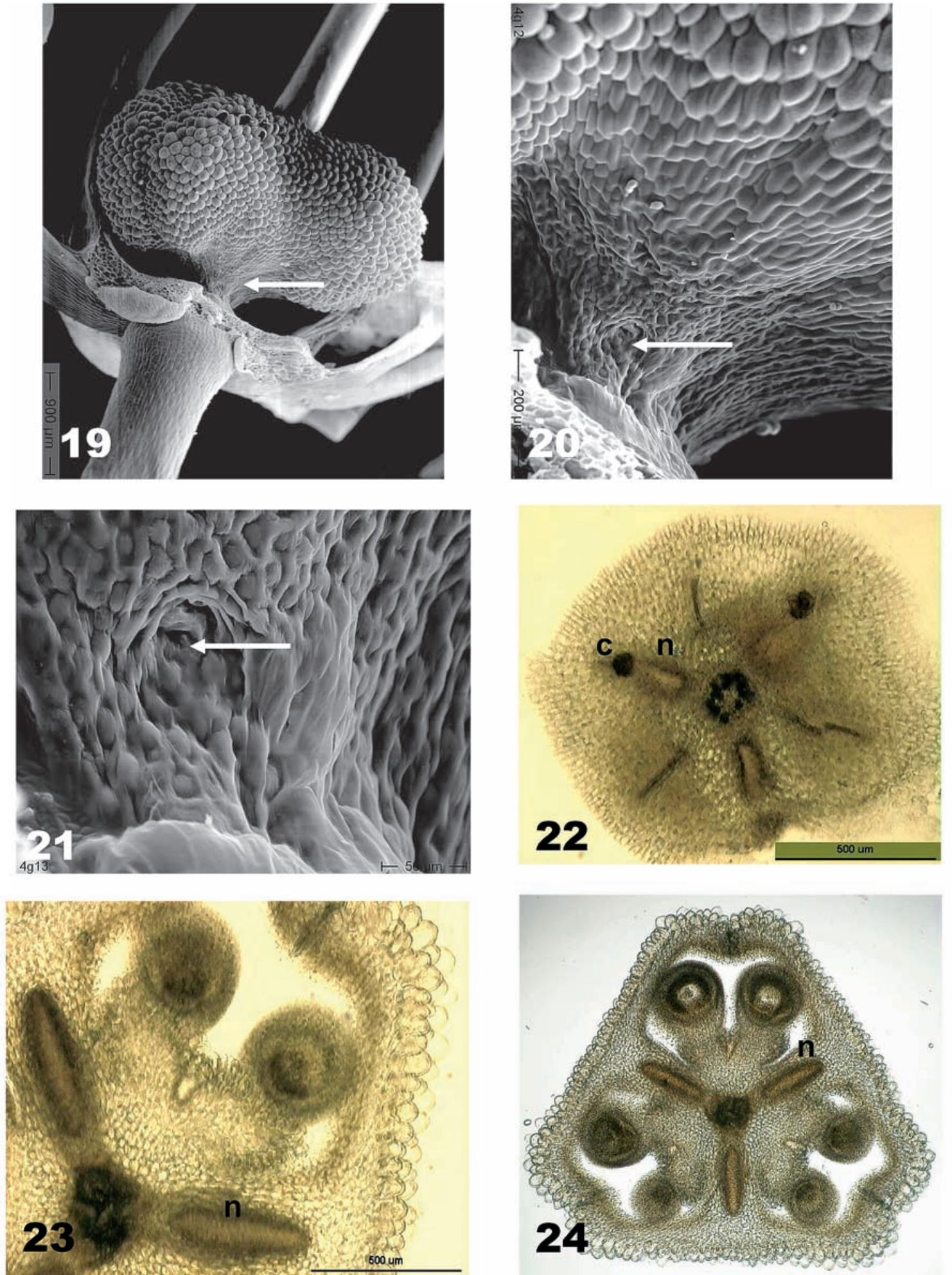

Fig. 19. The flattened ovary with the visible gynophore at the base (arrow)

Figs 20, 21. Portions of the ovary with the visible gynophore in which is visible the outlet of the duct carrying the nectar outside (arrows)

Fig. 22. Cross-sectional view of the gynophore in which are visible the septal nectaries (n) and the ducts (c) located next to them, with dark secretion (nectar)

Figs 23, 24. Cross-sections of the ovary with the visible septal nectaries (n), Fig. $24-x 25$ 


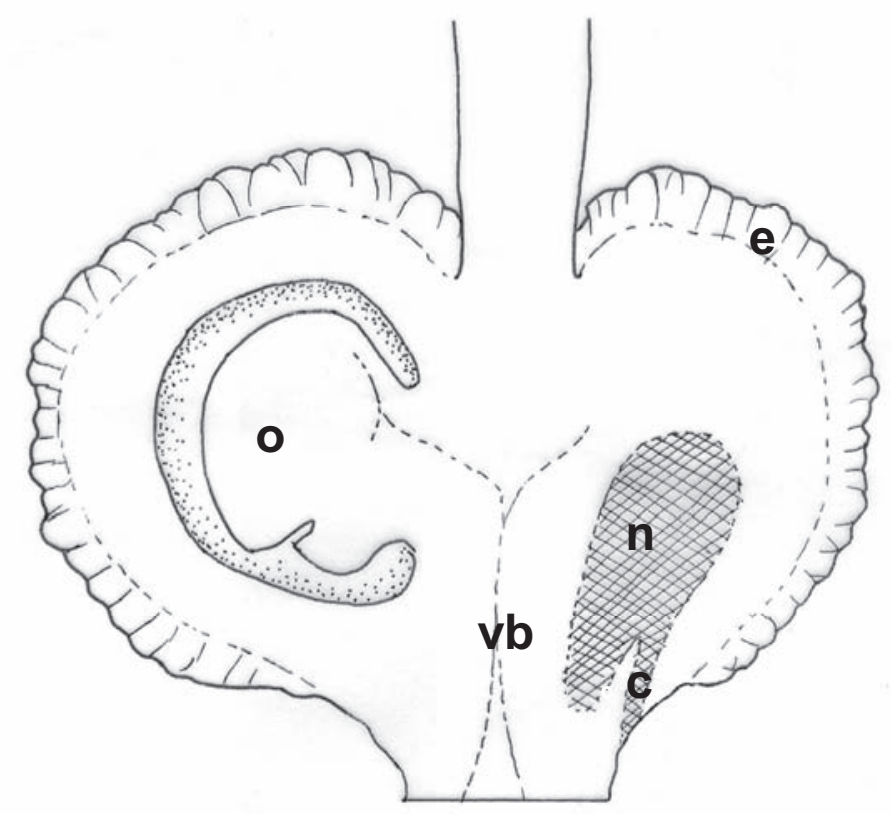

Fig. 25. A longitudinal schematic diagram of the pistil with the epidermis (e) of substantial thickness, ovule (o), vascular bundles (vb), nectary (n), and the duct (c) carrying the nectar outside, x 50

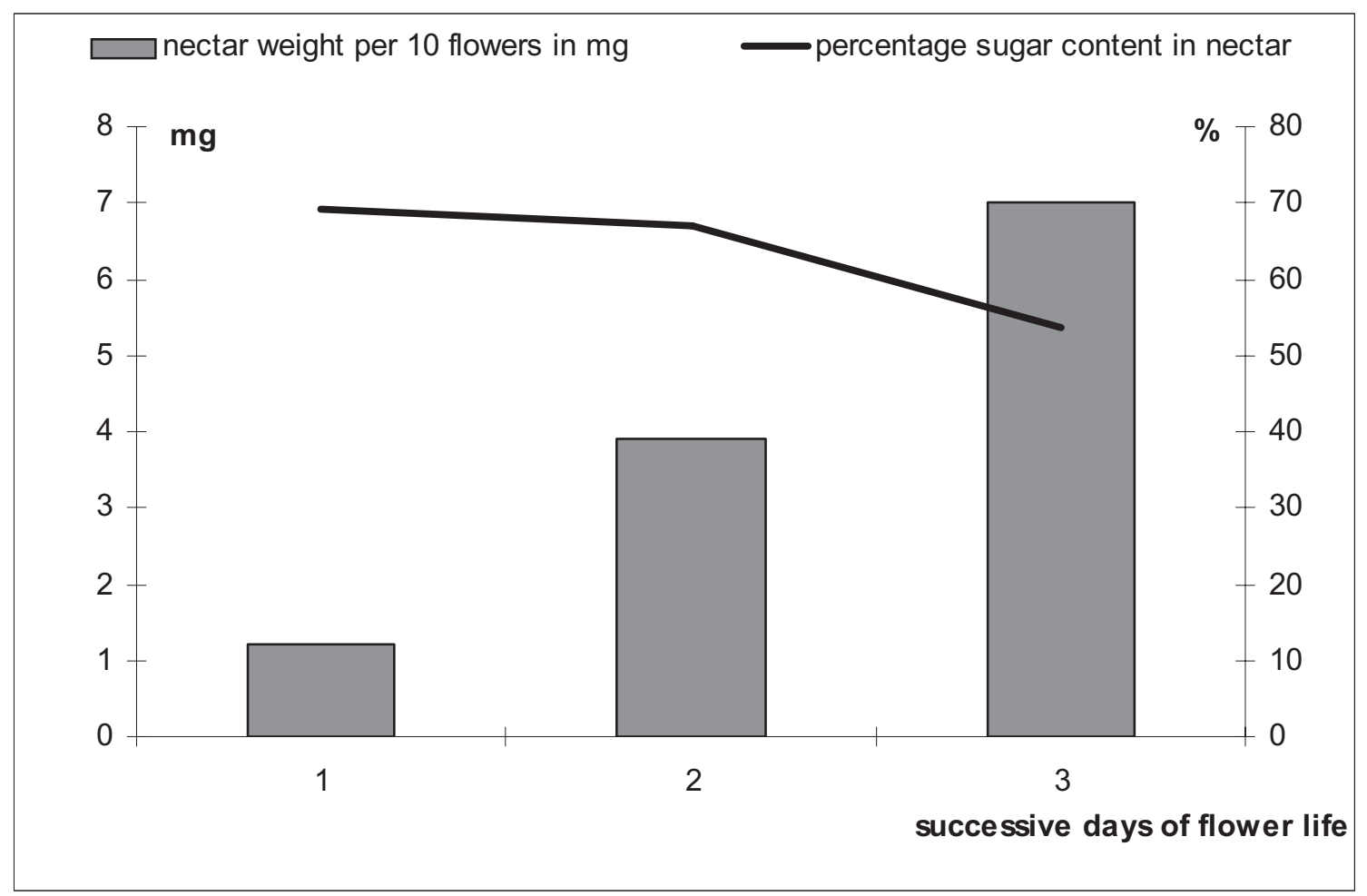

Fig. 26. Nectar weight and percentage content of sugars accumulated in 1-, 2- and 3-day-old flowers of A. giganteum 
The stamens of the inner whorl in A. giganteum have expanded bases of the filaments that are located opposite the outlet of the nectar-releasing ducts. These expansions are probably a protection preventing the nectar from flowing out of the flowers, and they are also found in other Allium species (M a u rizio and Graf 1, 1969; Weberling, 1992; Żuraw et al. 2009).

Allium giganteum has similar traits related to the ovary structure, the presence of the gynophore, the location of the nectary, and the nectar outlet, to the traits of $A$. aflatunense described in our earlier paper ( $\dot{Z}$ u r a w et al. 2009). The differences include a more flattened shape of the ovary and a shorter gynophore in A. giganteum. The septal nectaries in the flowers of A. giganteum are located in the lower part of the ovary, where the locules become narrowed down, while the septa are well-developed. The lowest part of the nectary is located below the ovary locules, whereas the outlet of the nectar-emitting duct is at the level of the short gynophore.

Nectar weight per 10 A. giganteum flowers averaged $6.93 \mathrm{mg}$. This value was higher than the results obtained for A. aflatunense (4.57 $\mathrm{mg}$ ) ( $\dot{\mathrm{Z}} \mathrm{u} \mathrm{r}$ a w et al. 2009). A comparison of the weight of nectar produced by one $A$. giganteum flower $(0.69 \mathrm{mg})$ with the data relating to other ornamental Allium species (0.2-1.2 mg) ( $\mathrm{S} \mathrm{zk} \mathrm{lanow} \mathrm{s} \mathrm{a,} \mathrm{1982)} \mathrm{shows} \mathrm{that} \mathrm{nectar} \mathrm{produc-}$ tion of the species in question is at an average level within this genus.

Sugar content in the nectar of $A$. giganteum reached an average value of $54.5 \%$ and was within the range (48\%-66\%) determined for ten other species of the genus Allium (S zklanow ska, 1982). Sugar weight per flower averaged $0.36 \mathrm{mg}$. This value is close to that obtained for A. aflatunense $(0.34 \mathrm{mg}$ ) ( $\dot{\mathrm{Z}} \mathrm{u} \mathrm{r}$ a w et al. 2009), but it is four times lower compared to the average results $(1.24 \mathrm{mg})$ obtained for three species of the subgenus Melanocrommyum (A. aflatunense, A. atropurpureum, A. christophii) ( $\dot{\mathrm{Z}} \mathrm{u} \mathrm{r}$ a w , 2008).

A very high sugar weight calculated for one A. giganteum inflorescence $(771.7 \mathrm{mg})$ is the result of a very large number of flowers clustered in a single inflorescence. This value is more than ten times higher than that estimated for one inflorescence of $A$. aflatunense (68.4 mg) ( $\dot{\mathrm{Z}} \mathrm{uraw}$ et al. 2009) and seven times higher compared to the average value (122.78 mg) obtained by $\dot{Z}$ u r a w (2008) for three representatives of Melanocrommyum.

\section{REFERENCES}

Hertogh de A. A., Zi m mer K., 1993. Allium - ornamental species. [In:] A. A. de Hertogh, M. Le Nard (eds), The physiology of flower bulbs. Elsevier, Amsterdam: 187-200.
Jabłoński B., 2003. Metodyka badań obfitości nektarowania kwiatów i oceny miododajności roślin. Wyd. Oddz. Pszczeln., Instytutu Sadownictwa i Kwiaciarstwa, Puławy (in Polish).

Kamenetsky R. and Fritsch R. M., 2002. Ornamental Alliums. [In:] H. D. Rabinowitch and L. Currah (eds), Allium Crop Science: Recent Advances. CABI Publ., Oxon: 459-491.

Konarska A., 2009. The biology of flowering and structure of selected elements of Cornus alba L. flowers. Acta Agrobot. 62 (1): 9-15.

Krzymińska A., 2003. Fenologia i morfologia wybranych gatunków ozdobnych czosnku (Allium L.). Zesz. Probl. Post. Nauk Rol. 491: 161-168 (in Polish).

K r z y m i ń sk a A., 2008. Ozdobne gatunki i odmiany czosnku (Allium L.). Analiza genetyczna i mikromorfologiczna. Metody pędzenia roślin. Rozprawy naukowe 392. Wydawnictwo Uniwersytet Przyrodniczy w Poznaniu (in Polish).

Maurizio A., Grafl I., 1969. Das Trachtpflanzenbuch. Ehrentwirth Verlag, München.

Rudal1 P. J., 2002. Homologies of inferior ovaries and septal nectaries in monocotyledons. Int. J. Plant Sci. 163: 261-276.

Smets E. F., Ronse Decraene L. P., Caris P., Rud a 11 P. J., 2000. Floral nectaries in Monocotyledons: distribution and evolution. [In:] K. L. Wilson and D. A. Morrison (eds), Monocots - systematics and evolution. CSIRO, Melbourne: 230-240.

Szk la nowska K., 1982. Wartość pszczelarska i owocowanie niektórych gatunków z rodzaju Allium L. [In:] Studia i Materiały III Seminarium „Zapylanie roślin warzywnych" Skierniewice: 216-243 (in Polish).

Vogel S., 1990. The role of scent glands in pollination on the structure and function of osmophores. A Merind Publishing Co., New Dehli, India.

Weberling F., 1992. Morphology of flowers and inflorescences. Cambridge Univ. Press, Cambridge.

Weryszko-Chmielewska E., Chwil M., Sawidis T., 2007. Micromorphology and histochemical traits of staminal osmophores in Asphodelus aestivus Brot. flower. Acta Agrobot. 60 (1): 13-23.

Weryszko-Chmielewska E. and Chwil M., 2008. Micromorphology of glandular structures in Echium vulgare L. flowers. Acta Agrobot. 61 (2): 25-34.

Żuraw B., 2007. Owady odwiedzające kwiaty ozdobnych gatunków z rodzaju Allium. Mat. z XLV Nauk. Konf. Pszczel., 24-25 kwietnia 2007, Puławy: 103-104 (in Polish).

Żu raw B., 2008. Nektarowanie kwiatów ozdobnych gatunków czosnku z podrodzaju Allium i Melanocrommyum. Mat. z XLV Nauk. Konf. Pszczel., 11-12 marca 2008, Puławy: 153-154 (in Polish).

Żuraw B., Weryszko-Chmielewska E., Laskowska H., Pogroszewska E., 2009. The structure of septal nectaries and nectar presentation in the flowers of Allium aflatunense B. Fedtsch. Acta Agrobot. 62 (2): 31-41. 


\section{Lokalizacja nektarników i wydzielanie nektaru w kwiatach Allium giganteum Regel}

\section{Streszczenie}

W kwiatach Allium występują nektarniki septalne, których ujście u poszczególnych gatunków tego rodzaju może się znajdować w różnych częściach zalążni. Kwiatostany tych roślin stanowią bogate źródło nektaru dla owadów.

Badano położenie i budowę nektarników septalnych w kwiatach Allium giganteum Regel. Wykorzystano mikroskopię świetlną i skaningową elektronową.
Stwierdzono, że nektarniki septalne położone są w dolnej części zalążni oraz w gynoforze, na którym wyrasta zalążnia. Sekrecja nektaru odbywa się do szczelin nektarnika, z których spływa kanalikami do trzech otworów położonych w górnej części gynoforu, skąd wydostaje się na zewnątrz w sąsiedztwie rozszerzonych części filamentów. Koncentracja cukrów w nektarze A. giganteum osiągnęła średnio $54,5 \%$, a ich masa oznaczona dla jednego kwiatu wynosiła $0,36 \mathrm{mg}$. W przeliczeniu na kwiatostan liczący ponad 2 tys. kwiatów masa cukrów wynosiła 771,7 mg. 